\title{
Shelf-life of vacuum and modified atmosphere packaged sliced pangasius catfish (Pangasianodon hypophthalmus) under refrigerated storage condition
}

\author{
MD. TARIQUL ISLAM*, ESMOUT JAHAN ALICE, SUSHMITA SAHA, MD. ABDUL \\ KARIM, MD. AMANULLAH, MASUDUR RAHMAN AND PAROMITA CHOWDHURY \\ Department of Fisheries, University of Rajshahi, Rajshahi 6205, Bangladesh \\ *Email: tariqrubd@gmail.com
}

\begin{abstract}
The effects of vacuum (VP) and 100\% $\mathrm{N}_{2}$ modified atmosphere packaging (MAP) on the quality and shelf-life of sliced pangasius catfish (Pangasianodon hypophthalmus) during refrigerated storage $\left(4^{\circ} \mathrm{C}\right)$ were investigated up to 12 days. The values of $\mathrm{pH}$, total volatile base nitrogen (TVB-N) and thiobarbituric acid reactive substance (TBARS) of sliced fish samples during storage under VP and MAP packaging were within the limit acceptable for chilled fish. Total viable count (TVC) of pangasius fish, on the other hand, gradually increased from the initial value of $4.32 \pm 0.04$ to $8.30 \pm 0.13 \mathrm{log}$ CFU/g on day 9 for non-sealed pack (control) and 7.64 \pm 0.12 and $8.34 \pm 0.07 \mathrm{log} \mathrm{CFU} / \mathrm{g}$ for VP and MAP on day 12. There were no significant $(p<0.05)$ differences in TVC values among the three packaging conditions during the storage period except on day 9 where significantly $(p<0.05)$ lower TVC values were observed in the VP sample compared to that of other samples. Based on the bacterial counts of $7 \log \mathrm{CFU} / \mathrm{g}$, which is considered as the upper acceptable limit for fresh and frozen fish, the shelf-life was determined as the excess of 6 days for control pack and MAP samples, and excess of 9 days for VP sample. Therefore, VP is a good option to increase the shelf-life of wet fish, which can be adopted by the superstores to display their products with extended shelf-life.
\end{abstract}

Keywords: Pangasius fish, Vacuum, MAP, Shelf-life

\section{Introduction}

Among the exotic fish species introduced in Bangladesh, catfish (Pangasianodon hypophthalmus) has become very popular among freshwater aquaculturists due to their easy culture system, resistance to impaired water quality and adaptability to intensive aquaculture high yield and low production cost, good taste, fewer intramuscular bones and high consumer acceptance (Sarker 2000). Total pangasius production in Bangladesh reached to 0.45 million metric tons in 2017-18, making it the second-largest single species contributor after hilsa (DoF 2018). Recently, its market price became very low compared to the production cost that discourages the farmer to culture this fish in Bangladesh. In this case, the development of different value-added products from pangasius fish may act as an alternative way to increase the value of fish (Viji et al. 2015).

Food preference has been changing with the social and economic development of the country. Now city-dwellers especially working mothers and housewives seek ready-to-cook (RTC) or prepared foods instead of raw ingredients in their busy life. Presently there is no such fishery product in the domestic market. In Bangladesh, fishes are usually sold as a whole with no proper storage and display facilities. As a result, considerable amounts of raw fishes undergo quality deterioration during retailing (Hossain et al. 2013). On the other hand, many retail superstores of the country now display the fresh fishes as whole fish, sometimes as whole 
dressed and hardly as portions under refrigeration or icing condition. As a result, consumers are restricted to buy the affordable portions of fishes, particularly for larger popular fishes. This chilled storage will not necessarily extend the shelf-life sufficiently for retail distribution and display purposes. Repeated thawing and freezing is another problem which is being practiced in retail superstores. As a consequence, the quality of the fishes is deteriorated, and a considerable portion is spoiled, which is one of the reasons for high pricing in those superstores. Fresh fishes are highly perishable products due to their biological composition. Even under normal refrigerated storage, the shelf-life of the products is short due to enzymatic, chemical and microbial spoilage. However, with increasing consumer demands of fresh products with prolonged shelf-life and rising energy costs associated with freezing and frozen storage, the fishprocessing industry and retail superstores are actively seeking an alternative method for the marketability of fresh, refrigerated fish and at the same time economizing on energy costs (Ashie et al. 1996).

Vacuum and modified atmosphere packaging are widely used packaging techniques used for displaying chilled fish, meat and their various products in developed countries. In vacuum packaging, the product is placed inside a type of plastic pouch having low permeability to oxygen, and the air is exhausted causing the bag to collapse around the product before it is sealed (Adams and Moss 2008). The gaseous atmosphere of vacuum packaging is changed, but it is probably altered during storage, thus considered modified due to a $10-20 \%$ increase in the $\mathrm{CO}_{2}$ amount produced by microbial activity utilizing residual oxygen. This $\mathrm{CO}_{2}$ may inhibit the growth of aerobic microflora generally associated with the spoilage of fish and fish products (Silliker and wolfe 1980). Modified atmosphere packaging (MAP) is a preservation method by altering the atmospheric environment around a perishable food with a single or a mixture of protective gas (Arashisar et al. 2004). MAP has been used successfully to extend the shelf-life (25-400\%) of the raw fillets of many fish species at refrigeration temperatures (Reddy et al. 1991, Pantazi et al. 2008). It allows retailers to sell fresh fishes at refrigeration conditions for an extended period. The growth of common spoilage bacteria is inhibited, and a microaerophilic group of lactic acid bacteria become the dominant spoilage organisms (Soccol and Oetterer 2003). Nitrogen $\left(\mathrm{N}_{2}\right)$ is used for dislocating the oxygen from the packaging, decreasing oxidative rancidity and inhibiting the growth of aerobic microorganisms. For its low solubility, it is used as a filler gas preventing the possible packaging collapse caused by the accumulation of $\mathrm{CO}_{2}$. Nitrogen also helps to prevent mould growth and insect attacks. It can indirectly influence the microorganisms in perishable foods by retarding the growth of aerobic spoilage organisms (Farber 1991, Phillips 1996). To ensure increased shelf-life and keeping quality, vacuum and MAP offer technological options to the fishery products. MAP lengthens the shelf-life of a product and reduces economic losses. This technology allows delivering the product to longdistance markets; therefore, the commercial value may increase (Pastoriza et al. 1996). This type of packaging system has not yet been developed in Bangladesh. The objective of this research was to determine the overall quality and shelf-life of sliced pangasius catfish under vacuum and MAP stored at $4{ }^{\circ} \mathrm{C}$.

\section{Materials and Methods}

Sample collection and preparation: Live pangasius catfish (Pangasianodon hypophthalmus) with an average size of $1 \mathrm{~kg}$ were purchased from the local market and brought to the Quality Control Laboratory of Department of Fisheries, Rajshahi University. Upon arrival, fishes were 
washed with tap water at room temperature. Then the fishes were dressed and cut into around 0.5 inch thick slices of having approximately $50 \mathrm{~g}$ of weight. Slices were washed two times with tap water at room temperature and the final wash was done with distilled water. At that time, the fish slices became ready for packaging.

Packaging and storage of samples: The required amount of sliced fishes was packed under vacuum and MAP in low gas and moisture permeable plastic pouches. The packaging material used for this purpose was a multi-layered transparent pouch (PE/PA/PE), having $100 \mu \mathrm{m}$ thickness. Three types of packaging were applied under vacuum and MAP using the method described by Noseda et al. (2012). Those three types of packaging were used as treatments namely, (1) aerobic, not sealed pack as control; (2) vacuum pack as treatment-1; and (3) MAP with $100 \% \mathrm{~N}_{2}$ pack as treatment-2. Vacuum and MA packaging was performed using a packaging machine (C100 Multivac, Haggenmuller, Germany) attached with a nitrogen gas cylinder according to the manufacturer's instruction. All the packaged samples were stored at $4^{\circ} \mathrm{C}$ in a laboratory refrigerator. Three samples from each packaging conditions were examined at storage days $0,3,6,9$, and 12 in the laboratory.

Biochemical and microbiological analyses: Biochemical and microbiological parameters were analysed at the laboratory to evaluate the quality of fish slices as well as to determine the shelflife under refrigerated storage. The $\mathrm{pH}$ value of the fish flesh homogenate was measured by means of a glass electrode $\mathrm{pH}$ meter (HI2002-Edge, Hanna Inst, USA). In this case, $10 \mathrm{~g}$ of cut flesh was homogenized with $50 \mathrm{~mL}$ of distilled water to make the homogenate. Total volatile base nitrogen (TVB-N) was determined using $10 \mathrm{~g}$ of ground fish sample with perchloric acid according to EC (2005) method. Thiobarbituric acid reactive substances (TBARS) values were measured by colourimetric method using a spectrophotometer (1601PC, Shimadzu, Japan) according to the procedure of Witte et al. (1970). TBARS values was calculated as follows: TBARS value $(\mathrm{mg}$ malonaldehyde $/ \mathrm{kg}$ ) $=$ optical density $($ O.D. $) \times 5.2$. Total viable count $($ TVC) was determined by a standard plate count method on plate count agar following APHA (1992) method. Plates were incubated at $35^{\circ} \mathrm{C}$ in an incubator for $48 \mathrm{~h}$ and colonies were counted.

Statistical analysis: The values were expressed as mean \pm standard deviation. Differences among treatments were estimated by using one-way ANOVA with the application of a Tukey test using SPSS version-20 (IBM, Chicago, IL). Average values were considered significantly different when $p<0.05$.

\section{Results and Discussion}

The present study was undertaken to assess the shelf-life of sliced pangasius catfish $(P$. hypophthalmus) under vacuum and modified atmosphere packaging at $4{ }^{\circ} \mathrm{C}$. Various biochemical parameters namely; $\mathrm{pH}$, TVB-N, TBARS value and bacterial load in terms of TVC were monitored during 12 days of storage period.

Changes in $\boldsymbol{p H}$ : Muscle $\mathrm{pH}$ is an indicator of the extent of microbial growth in fish; some proteolytic bacteria can produce acid after decomposition of carbohydrates, thereby increasing the acid level of the fish. The $\mathrm{pH}$ of freshwater fish flesh in the fresh condition is almost neutral (Virta 2009). The decomposition of nitrogenous compounds leads to an increase in the $\mathrm{pH}$ in the fish flesh at the post-mortem period (Shenderyuk and Bykowski 1989). The post-mortem pH 
acceptability limit is usually $6.8 \sim 7.0$ (Metin et al. 2001). Changes in muscle pH of refrigerated sliced pangasius fishes under different packaging conditions are shown in Table I. The initial $\mathrm{pH}$ was $6.68 \pm 0.13$ and then decreased up to $3^{\text {rd }}$ day of storage for control and vacuum packed and $6^{\text {th }}$ day for $\mathrm{N}_{2}$ packed samples. After that, the $\mathrm{pH}$ values gradually increased with some fluctuation sunder all packaging conditions during the storage period. However, significantly $(p<0.05)$ lower $\mathrm{pH}$ values were observed on the $6^{\text {th }}$ and $9^{\text {th }}$ day of storage in all packed samples compared to those of control (Table I). The $\mathrm{pH}$ values were within the acceptable limit in all packaging conditions during the storage period. Generally, the low muscle $\mathrm{pH}$ of muscle postmortem is associated with the quality changes in fish (Kramer and Peters 1981, Reza et al. 2009). There is a direct relation between TVB- $\mathrm{N}$ and $\mathrm{pH}$ value and the microbial spoilage, which leads to autolysis in the fish tissue. Changes in $\mathrm{pH}$, microbial growth, trimethylamine and volatile protein nitrogen have been used as indices of the freshness of iced aquatic species (Cheuk et al. 1979).

Table I. pH value of sliced pangasius fishes under different packaging conditions at refrigerated storage

\begin{tabular}{lccccc}
\hline \multirow{2}{*}{ Treatments } & \multicolumn{5}{c}{ Storage period (days) } \\
\cline { 2 - 6 } & 0 & 3 & 6 & 9 & 12 \\
\hline Not sealed pack (Control) & $6.68 \pm 0.13^{\mathrm{a}}$ & $6.40 \pm 0.31^{\mathrm{a}}$ & $6.90 \pm 0.03^{\mathrm{c}}$ & $6.71 \pm 0.25^{\mathrm{b}}$ & $6.82 \pm 0.15^{\mathrm{a}}$ \\
Vacuum pack & $6.68 \pm 0.13^{\mathrm{a}}$ & $6.03 \pm 0.26^{\mathrm{a}}$ & $6.48 \pm 0.17^{\mathrm{b}}$ & $6.04 \pm 0.14^{\mathrm{a}}$ & $6.48 \pm 0.14^{\mathrm{a}}$ \\
Nitrogen (100\%) pack & $6.68 \pm 0.13^{\mathrm{a}}$ & $6.38 \pm 0.05^{\mathrm{a}}$ & $5.99 \pm 0.18^{\mathrm{a}}$ & $6.19 \pm 0.10^{\mathrm{a}}$ & $6.55 \pm 0.39^{\mathrm{a}}$ \\
\hline
\end{tabular}

Different superscripts in the same column represent a significant difference among the means of treatments $(p<0.05)$

The initial declining trend of $\mathrm{pH}$ probably occurred due to the accumulation of lactic acid by anaerobic glycolysis and the liberation of inorganic phosphates by the degradation of ATP. This is in agreement with the results reported by Ayala et al. (2010) for sea bream during 22 days of ice storage. On the other hand, the increasing trend of $\mathrm{pH}$ at later stages of storage may be occurred due to the production of amines and other volatile bases by the autolytic and microbial action on protein and other components of fish (Wang and Brown 1983, Binsi et al. 2007). Similar increasing behaviour was observed during storage in brined chub mackerel at refrigerated temperature (Goulas and Kontominas 2005).

Changes in TVB-N: TVB-N is an important characteristic for the assessment of the quality of fish and fishery products. The combination of the total amount of ammonia $\left(\mathrm{NH}_{3}\right)$, di- and trimethylamine in fish is called total volatile base (TVB) nitrogen and is commonly used as an index of fish freshness (Wu and Bechtel 2008). European Union directive on fish hygiene specifies that if the organoleptic examination shows any doubt as to the freshness of the fish, inspectors must use TVB-N as a chemical check (Castro et al. 2006). The acceptable limit of TVB-N value for freshly caught fish is $5.6 \mathrm{mg} / 100 \mathrm{~g}$, and ice-stored fish is $30-35 \mathrm{mg} / 100 \mathrm{~g}$ of fish (Connell 1995).

In the present study, the initial TVB-N value of pangasius fish slices was $2.38 \pm 0.20$ $\mathrm{mg} / 100 \mathrm{~g}$, and then, the values gradually increased with progressing storage time under all packaging conditions. The range of TVB-N value was $2.38 \pm 0.20$ to $5.18 \pm 0.99 \mathrm{mg} / 100 \mathrm{~g}$ during the storage period. No significant $(p>0.05)$ differences were observed in relation to TVB-N values among three packaging conditions. However, the values were within the acceptable limit 
SHELF-LIFE OF PACKAGED SLICED PANGASIUS CATFISH UNDER REFRIGERATION

of $30-35 \mathrm{mg} / 100 \mathrm{~g}$ for iced fish in all packaging conditions (Table II). A more or less similar result was reported by Soccol et al. (2005) where there were no significant differences on TVB$\mathrm{N}$ values among the treatments of tilapia fish (air, vacuum, and a MAP with $60 \% \mathrm{CO}_{2} / 40 \% \mathrm{O}_{2}$ ) during the 20 days of storage at $1{ }^{\circ} \mathrm{C}$. The amount of TVB-N in fish increases as spoilage progresses. An increase in TVB-N during storage is a consequence of the liberation of basic compounds by microbial activity on protein and non-protein nitrogenous compounds. As a result, the $\mathrm{pH}$ also increased at later stages of storage due to the production of basic components such as ammonia, dimethylamine, trimethylamine, other biogenic amines (Goulas and Kontominas 2007).

Table II. TVB-N value (mg/100g) of sliced pangasius fishes under different packaging conditions at refrigerated storage

\begin{tabular}{lccccc}
\hline \multirow{2}{*}{ Treatments } & \multicolumn{5}{c}{ Storage period (days) } \\
\cline { 2 - 6 } & 0 & 3 & 6 & 9 & 12 \\
\hline Not sealed pack (Control) & $2.38 \pm 0.20^{\mathrm{a}}$ & $2.24 \pm 0.79^{\mathrm{a}}$ & $2.66 \pm 0.20^{\mathrm{a}}$ & $3.64 \pm 0.40^{\mathrm{a}}$ & $5.01 \pm 0.29^{\mathrm{a}}$ \\
Vacuum pack & $2.38 \pm 0.20^{\mathrm{a}}$ & $2.21 \pm 0.61^{\mathrm{a}}$ & $2.52 \pm 1.19^{\mathrm{a}}$ & $3.64 \pm 1.19^{\mathrm{a}}$ & $4.62 \pm 0.59^{\mathrm{a}}$ \\
Nitrogen (100\%) pack & $2.38 \pm 0.20^{\mathrm{a}}$ & $1.68 \pm 0.40^{\mathrm{a}}$ & $1.96 \pm 1.19^{\mathrm{a}}$ & $5.18 \pm 0.99^{\mathrm{a}}$ & $4.34 \pm 0.20^{\mathrm{a}}$ \\
\hline Different superscripts in the same column represent a significant difference among the means of treatments $(p<0.05)$
\end{tabular}

Changes in TBARS value: TBARS is a measure of one of the secondary lipid oxidation products, the malonaldehyde. The results are expressed with regard to the standard malonaldehyde used and reported as micromoles malonaldehyde present in $1 \mathrm{~g}$ of fat. The acceptable limit of TBARS value is $2 \mathrm{mg}$ malonaldehyde/ $\mathrm{kg}$ fish. However, beyond this limit, an objectionable odour and taste develop in fish (Connell 1990). Therefore, it can be used as a quality indicator of food products. In the present study, the initial TBARS value was $0.30 \pm 0.09$ $\mathrm{mg}$ malonaldehyde $/ \mathrm{kg}$ of sliced pangasius fish, and then, values increased rapidly for not sealed pack, and slowly for vacuum and nitrogen packed samples during refrigerated storage. Significantly $(p<0.05)$ lower TBARS values were observed on the $6^{\text {th }}, 9^{\text {th }}$, and $12^{\text {th }}$ day of storage in the vacuum pack sample compared to that of the control sample (Table III). However, the TBARS values were within the acceptable limit $(2 \mathrm{mg}$ malonaldehyde $/ \mathrm{kg})$ in all samples during the storage period. Sallam et al. (2006) observed almost similar initial TBARS value ( $0.37 \mathrm{mg}$ malonaldehyde $/ \mathrm{kg}$ ) in fresh raw Pacific saury. In the present study, lower TBARS values were observed in the case of vacuum and nitrogen pack samples due to the absence of oxygen in those packs. According to Aubourg (1993), TBARS records may not reveal the actual rate of lipid oxidation as malonaldehyde may interact with other components of fish muscle such as amines, nucleosides, and nucleic acid, proteins, amino acids of phospholipids, and other aldehydes that are end products of lipid oxidation and this interaction may vary significantly with fish species. The usefulness of thiobarbituric acid (TBA) value and Thiobarbituric acid reactive substances (TBARS) as an indicator of shelf-life depends on the type of product (DeWitt and Oliveira, 2016). Alfaro et al. (2013) determined that TBA was not a useful indicator for shelf-life determination of MAP of Atlantic horse mackerel, while Torrieri et al. (2011) found TBARS to be a critical index for determination of shelf-life of MAP of Bluefin tuna. 
MD. TARIQUL ISLAM et al.

Table III. TBARS value (mg malonaldehyde/kg) of sliced pangasius fishes under different packaging conditions at refrigerated storage

\begin{tabular}{lccccc}
\hline \multirow{2}{*}{ Treatments } & \multicolumn{5}{c}{ Storage period (days) } \\
\cline { 2 - 6 } & 0 & 3 & 6 & 9 & 12 \\
\hline Not sealed pack (Control) & $0.30 \pm 0.09^{\mathrm{a}}$ & $0.33 \pm 0.06^{\mathrm{a}}$ & $0.67 \pm 0.09^{\mathrm{b}}$ & $0.93 \pm 0.04^{\mathrm{c}}$ & $1.12 \pm 0.03^{\mathrm{b}}$ \\
Vacuum pack & $0.30 \pm 0.09^{\mathrm{a}}$ & $0.25 \pm 0.06^{\mathrm{a}}$ & $0.37 \pm 0.13^{\mathrm{a}}$ & $0.44 \pm 0.08^{\mathrm{b}}$ & $0.58 \pm 0.04^{\mathrm{a}}$ \\
Nitrogen (100\%) pack & $0.30 \pm 0.09^{\mathrm{a}}$ & $0.17 \pm 0.09^{\mathrm{a}}$ & $0.40 \pm 0.10^{\mathrm{ab}}$ & $0.23 \pm 0.07^{\mathrm{a}}$ & $0.64 \pm 0.05^{\mathrm{a}}$ \\
\hline
\end{tabular}

Different superscripts in the same column represent a significant difference among the means of treatments $(p<0.05)$

Changes in TVC: TVC is an important measure for the assessment of the microbial quality of a food product. The initial TVC of sliced pangasius fish was $4.32 \pm 0.04 \log \mathrm{CFU} / \mathrm{g}$ on plate count agar that indicated an acceptable initial quality of fish. Most of the available literature on freshly caught freshwater fishes (seabass, tilapia, rainbow trout, and silver perch) reported bacterial counts of 2-6 $\log$ CFU/g (Gelman et al. 2001). In the present study, the TVC gradually increased with the progression of storage time in all packaging conditions. There were no significant differences in TVC observed among all packaging conditions until the $6^{\text {th }}$ day of storage. However, significantly $(p<0.05)$ lower TVC was observed on the $9^{\text {th }}$, and $12^{\text {th }}$ day of storage in the vacuum pack sample compared to that of other samples (Table IV).

Table IV. Total viable count (log CFU/g) of sliced pangasius fishes under different packaging conditions at refrigerated storage

\begin{tabular}{lccccc}
\hline \multirow{2}{*}{ Treatments } & \multicolumn{5}{c}{ Storage period (days) } \\
\cline { 2 - 6 } & 0 & 3 & 6 & 9 & 12 \\
\hline Not sealed pack (Control) & $4.32 \pm 0.04^{\mathrm{a}}$ & $4.26 \pm 0.12^{\mathrm{a}}$ & $6.24 \pm 0.28^{\mathrm{a}}$ & $8.30 \pm 0.13^{\mathrm{b}}$ & - \\
Vacuum pack & $4.32 \pm 0.04^{\mathrm{a}}$ & $5.44 \pm 0.53^{\mathrm{a}}$ & $5.83 \pm 0.55^{\mathrm{a}}$ & $6.87 \pm 0.41^{\mathrm{a}}$ & $7.64 \pm 0.12^{\mathrm{a}}$ \\
Nitrogen (100\%) pack & $4.32 \pm 0.04^{\mathrm{a}}$ & $4.93 \pm 0.38^{\mathrm{a}}$ & $6.63 \pm 0.19^{\mathrm{a}}$ & $7.91 \pm 0.24^{\mathrm{b}}$ & $8.34 \pm 0.07^{\mathrm{b}}$ \\
\hline
\end{tabular}

Different superscripts in the same column represent a significant difference between the means of treatments $(p<0.05)$

The TVC values exceeded the $7 \mathrm{log} \mathrm{CFU} / \mathrm{g}$, which is considered as the upper acceptable limit for fresh and frozen fish and cold-smoked fish species (ICMSF, 1986) after $6^{\text {th }}$ day for not sealed pack (control), after $9^{\text {th }}$ day for vacuum pack, and after $6^{\text {th }}$ day of storage for nitrogen pack sample (Fig. 1). Taking the $7 \mathrm{log}$ CFU/g as the maximum acceptable limit for fresh, frozen and cold-smoked fish species, the shelf-life of sliced pangasius fish was determined at the excess of 6 days for not sealed pack \& nitrogen pack sample and excess of 9 days for vacuum pack sample. 


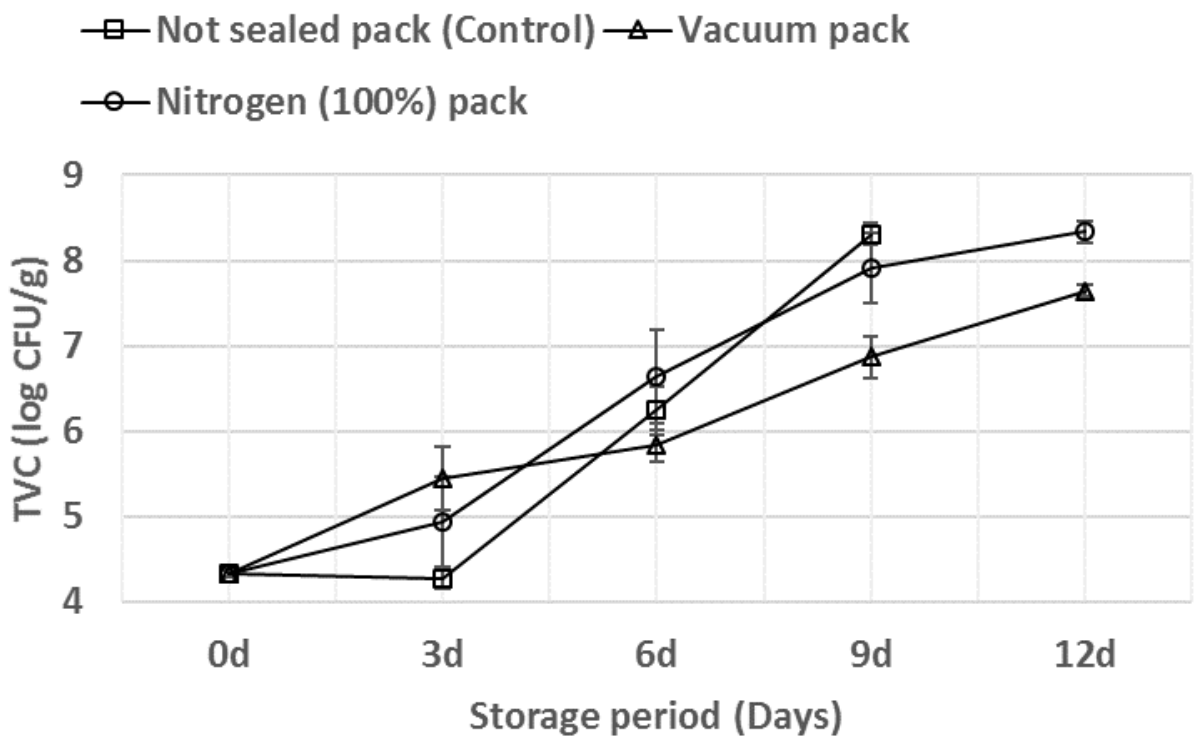

Fig. 1. Changes in the total viable count $(\log \mathrm{CFU} / \mathrm{g})$ of sliced pangasius fishes under different packaging conditions at refrigerated storage

There is an agreement with several studies including Davis (2003) who found higher TVC on aerobic, not sealed pack sample compared to MAP samples which exceed the limit after 10 days of storage. Reddy et al. (1995) reported a higher shelf-life of MA-packaged $\left(75 \% \mathrm{CO}_{2} / 25\right.$ $\mathrm{N}_{2}$ ) tilapia fillets stored at $4{ }^{\circ} \mathrm{C}$ that is of $>25$ days based on microbial evaluation which is longer than the finding from this study. This is due to the use of a high amount of carbon dioxide along with nitrogen. Therefore, only nitrogen flushing is not enough to increase product shelf-life. In the present study, the best performance was observed for vacuum packaging, as the slightly lower bacterial count was observed during the storage period compared to other packaging conditions. Vacuum packaging creates anaerobic conditions inside the pack; as a result, aerobic bacterial growth is inhibited, oxidative rancidity is retarded, and subsequently, the shelf-life is enhanced.

\section{Conclusions}

Vacuum and modified atmosphere packaging are getting popular with the consumer due to providing quality fishery products. It can also ensure other quality attributes, such as stabilizing the colour of the product and prevent objectionable odour development. The application of vacuum and modified atmosphere packaging in combination with chilling storage can delay or inhibit the microbial activities and increase the shelf-life of fish and fishery products. By evaluating all the biochemical and microbiological analyses, it can be concluded that vacuum packaging technology extends the shelf-life and improve the overall quality of pangasius fish compared to other packaging conditions. High production cost, the requirement of skilled staff, chemical and microbiological hazards in raw fish are some of the limitations seeming significant for developing MAP technology. Quality packaging material with various optimized 
combination of gas mixtures and hazard-free fresh fish has prospects for developing MAP technology in Bangladesh. Therefore, the superstores of the country can adopt this packaging technology to supply the quality fish and fishery products for the consumers.

Acknowledgement: The authors acknowledge the financial support for this research provided by the University Grants Commission (UGC) of Bangladesh through the Faculty of Agriculture, University of Rajshahi, Bangladesh.

\section{Literature Cited}

Adams, R.M. and O.M. Moss, 2008. Food Microbiology, 3rd edition. University of Surrey, RSC publishers, Guildford, UK.

Alfaro, B. and I. Hernandez, 2013. Evolution of the indigenous microbiota in modified atmosphere packaged Atlantic horse mackerel (Trachurus trachurus) identified by conventional and molecular methods. Int. J. Food Microbiol., 167: 117-123.

APHA (American Public Health Association), 1992. Compendium of Methods for the Microbiological Examination of Foods. 3rd edition, C Vander dent, and splittstoesser, D, (eds). APHA, Washington DC. $1264 \mathrm{p}$.

Arashisar, S., O. Hisar, M. Kaya and T. Yanik, 2004. Effects of modified atmosphere and vacuum packaging on microbiological and chemical properties of rainbow trout (Oncorynchus mykiss) fillets. Int. J. Food Microbiol., 97 (2): 209-14.

Ashie, I.N.A., J.P. Smith, B.K. Simpson, and N.F. Haard, 1996. Spoilage and shelf-life extension of fresh fish and shellfish. Crit. Rev. Food Sci. Nutr., 36(1-2): 87-121.

Aubourg, S.P., 1993. Review: Interaction of malondialdehyde with biological molecules- new trends about reactivity and significance. Int. J. Food Sci. Tech., 28: 323-335.

Ayala, M.D., I. Abdel, M. Santaella, C. Martinez, M.J. Periago, F. Gil, A. Blanco and O. L. Albors, 2010. Muscle tissue structural changes and texture development in sea bream, Sparus aurata L, during post-mortem storage. Food Sci. Tech., 43: 465-475.

Binsi, P.K., B.A. Shamasundar and A.O. Dileep, 2007. Physico-chemical and functional properties of proteins from green mussel (Pernaviridis) during ice storage. J. Sci. Food Agric., 87: 245-254.

Castro, P., J.C.P. Padro and M.J.C. Cansino, 2006. Total volatile base nitrogen and its use to assess freshness in European sea bass stored in ice. Food Control, 17: 245-248.

Cheuk, W.L., G. Finne and I.R. Nickelson, 1979. Stability of adenosine deaminase and adenosine monophosphate deaminase during ice storage of pink and brown shrimp from the Gulf of Mexico. $J$. Food Sci. 44 (1): 1625-1628.

Connell, J.J. 1990. Control of Fish Quality, $3^{\text {rd }}$ edition. Fishing News Books, Oxford, UK.

Connell, J.J. 1995. Control of Fish Quality, $4^{\text {th }}$ edition. Fishing News Books, a division of Blackwell Scientific Ltd. pp. 30.

Davis, H. K. 2003. Fish and Shellfish. Principles and Applications of Modified Atmosphere Packaging of Foods. Blackie Academic \& Professional, London. pp. 194-239.

DeWitt, C. A. M. and A.C.M. Oliveira. 2016. Modified atmosphere systems and shelf life extension of fish and fishery products. Foods, 5(3): 48.

DoF, 2018. Yearbook of Fisheries Statistics of Bangladesh, 2017-18. Fisheries Resources Survey System (FRSS), Department of Fisheries. Ministry of Fisheries and Livestock, Bangladesh. 129 p.

EC, 2005. Chapter III, Determination of the concentration of TVB-N in fish and fishery products. Commission Regulation (EC) No 2074, Official J. EU. L-37: 338.

Farber, J.M., 1991. Microbiological aspects of modified-atmosphere packing technology-A review. J. Food Sci., 9: 58-70.

Gelman, A., L. Glatman, V. Drabkin and S. Harpaz, 2001. Effects of storage temperature and preservative treatment on shelf-life of the pond-raised fresh water fish, silver perch (Bidyanus bidyanus). J. Food Protect., 64: 1584-1591. 


\section{SHELF-LIFE OF PACKAGED SLICED PANGASIUS CATFISH UNDER REFRIGERATION}

Goulas, A.E. and M.G. Kontominas, 2005. Effect of salting and smoking method on the keeping quality of chub mackerel (Scomberjaponicus): biochemical and sensory attributes. Food Chem., 93: 511-520.

Goulas, A.E. and M.G. Kontominas, 2007. Effect of modified atmosphere packaging and vacuum packaging on the shelf life of refrigerated chub mackerel (Scomber japonicus): biochemical and sensory attributes. Eur. Food Res. Technol., 224: 545-553.

Hossain, M.M., M. Rahman, M.N. Hassan and A.K.M. Nowsad Alam, 2013. Post-harvest loss of farm raised Indian and Chinese major carps in the distribution channel from Mymensingh to Rangpur of Bangladesh. Pak. J. Biol. Sci., 16: 564-569.

ICMSF (International Commission of Microbiological Specification for Food). 1986. Microorganisms in Food-2, Sampling for microbiological analysis: Principles and Specific Applications (2 ${ }^{\text {nd }}$ ed.), University of Toronto Press, Toronto.

Kramer, D.E. and M.D. Peters, 1981. Effect of $\mathrm{pH}$ and refreezing treatment on the texture of yellowtail rockfish (Sebastes flavidus) as measured by Ottawa texture measuring system. J. Food Tech., 16: 493-504.

Metin, S., N. Erkan, C. Varlik and N. Aran, 2001. Extension of shelf-life of chub mackerel (Scomber japonicas Houttuyn 1780) treated with lactic acid. Eur. Food Res. Technol., 213: 174-177.

Noseda, B., M.T. Islam, M. Eriksson, M. Heyndrickx, K.D. Reu, H.V. Langenhove and F. Devlieghere, 2012. Microbiological spoilage of vacuum and modified atmosphere packaged Vietnamese $P$. hypophthalmus fillets. Food Microbiol., 30 (2): 408-419.

Pantazi, D., A. Papavergou, N. Pournis, M.G. Kontominas and I.N. Savvaidis, 2008. Shelf-life of chilled fresh Mediterranean swordfish (Xiphias gladius) stored under various packaging conditions: microbiological, biochemical and sensory attributes. Food Microbiol., 25 (1): 136-143.

Pastoriza, L., G. Sampedro, J. J. Herrera, and M. L. Cabo. 1996. Effect of carbon dioxide atmosphere on microbial growth and quality of salmon slices. J. Sci. Food. Agr. 72(3): 348-352.

Phillips, C.A., 1996. Review: modified atmosphere packaging and its effects on the microbiological quality and safety of the products. Int. J. Food Sci. Technol., (31): 463-479.

Reddy, N.R., D.J. Armstrong, E.J. Rhodehamel and D.A. Kauter, 1991. Shelf-life extension and safety concerns about fresh fishery products packaged under modified atmospheres: a review. J. Food Safety, 12: 87-118.

Reddy, N.R., M. Villanueva and D.A. Kautter, 1995. Shelf life of modified-atmosphere-packaged fresh tilapia fillets stored under refrigeration and temperature-abuse conditions. J. Food Protect., 58: 908914.

Reza, M.S., M.A.J. Bapary, C.T. Ahasan, M.N. Islam and M. Kamal, 2009. Shelf life of several marine fish species of Bangladesh during ice storage. Int. J. Food Sci. Tech., 44: 1485-1494.

Sallam, Kh. I., A.M. Ahmed and M.M. Elgazzar, 2006. Chemical quality and sensory attributes of marinated Pacificsaury (Cololabis saira) during vacuum-packaged storage at $4^{\circ} \mathrm{C} . J$. Food Chem., 102: 106-110.

Sarker, M.T., 2000. Pangus Chash Babosthapana (Management of Pangus culture). Department of Fisheries (DoF), Bangladesh. 25 p.

Shenderyuk, V.I. and P.J. Bykowski, 1989. Salting and marinating of fish. In: Z.E. Sikorski (ed.). Seafood: Resources, Nutritional Composition, and Preservation. CRC Press Inc. Boca. Raton Florida.

Silliker, J.H. and S.K. Wolfe, 1980. Microbiological safety considerations in controlled-atmosphere storage of meats. Food Technol., 34: 59-63.

Soccol, M.C.H. and M. Oetterer, 2003. Use of modified atmosphere in seafood preservation. Brazilian Arch. Biol. Technol., 46(4): 569-580.

Soccol, M.C.H., M. Oetterer, C.R. Gallo, M.F. Spoto, and D.O. Biato, 2005. Effects of modified atmosphere and vacuum on shelf life of tilapia (Oreochromis niloticus) fillets. Braz. J. Food Tech., 8: $7-15$.

Torrieri, E., P.A. Carlino, S. Cavella, V. Fogliano, I. Attianese, G.G. Buonocore and P. Masi, 2011. Effect of modified atmosphere and active packaging on the shelf-life of fresh Bluefin tuna fillets. $J$. Food Eng., 105: 429-435. 
Viji, P., S. Tanuja, G. Ninan, K. Lalitha, A.A. Zynudheen, P.K. Binsi and T.K. Srinivasagopal, 2015. Biochemical, textural, microbiological and sensory attributes of gutted and ungutted Sutchi catfish (Pangasianodon hypophthalmus) stored in ice. J. Food Sci. Technol., 52(6): 3312-3321.

Virta, S., 2009. Isolation and identification of Rainbow Trout spoiling microbiota. Bachelor's Thesis, Biotechnology and Food Technology, Turku University of Applied Science, Finland. 8 p.

Wang, M.Y. and W.O. Brown, 1983. Effect of elevated $\mathrm{CO}_{2}$ atmosphere storage of freshwater crayfish (Pacifastacus leniusculus). J. Food Sci., 48: 158-162.

Witte, V.C., G.F. Krause and M.E. Bailey, 1970. A new extraction method for determining 2thiobarbituric acid values of pork and beef during storage.J. Food Sci., 35: 582-585.

$\mathrm{Wu}$, T.H. and P.J. Bechtel, 2008. Ammonia, dimethylamine, trimethylamine, and trimethylamine oxide from raw and processed fish by-products. J. Aquat. Food. Prod. Technol., 17: 27-38.

(Manuscript received 7 January 2020) 